\title{
Winged women on book covers for contemporary African fiction: Shubnum Khan's creation for Mohale Mashigo's Intruders (2018)
}

\author{
Prof Lize Kriel \\ Visual Culture Studies \\ School of the Arts, University of Pretoria, South Africa \\ Email: lize.kriel@up.ac.za \\ Orcid: https://orcid.org/0000-0002-2933-2215 \\ Doi: https://doi.org/10.46222/pharosjot.102.109
}

\begin{abstract}
In her collection of short stories, Intruders, Mohale Mashigo (2018) draws on popular culture as well as local cultural memories as invested in South African folktales, to conjure up a fantastical world in which spirituality is often invoked. In this article, I consider the way in which the visual image of a woman with angelic wings designed for the book cover by artist Shubnum Khan, serves the purpose of marketing the commodity by means of connotations presumed to be familiar to potential readers, but also still suggestive enough to stimulate, rather than prescribe, the visual imagination ignited in the process of reading. I link book cover designer Peter Mendelsund's argument that the reading imagination, although fuelled by memory, remains "loosely associative" and "not overtly coherent", with Ingvild Gilhus's cultural-historical appraisal of the angel's appeal as such a malleable symbol of (increasingly, specifically) female superhuman capabilities. I argue that the cover image 'works' because of its ability to kindle memories of precolonial African spirituality, associations with Christianity, as well as images circulating in mass media.
\end{abstract}

Keywords: Mohale Mashigo, Intruders, Shubnum Khan, book cover art, winged women.

\section{Introduction ${ }^{1}$}

"They travel light, tend to slip through the cultural net, and adapt to new circumstances." This is how Ingvild Gilhus (2019: 14) describes angels in her overview of their millennia-old history all around the world. Gilhus (2019: 11) comments on the "catchiness" of these hybrid, superhuman beings with wings - although some have also been represented as wingless. Gilhus (2019: 14) also points to the tendency in popular culture over the past century for angels to have become kind, female helpers. But, as will also be seen in this essay, popular culture has sometimes reincarnated, in female heroes, the fieriness and warrior characteristics of 'older' angels. Another old association, of angels as messengers entrusted with the power of the $w(W) o r d$, resonates in popular culture where the wings that women grow seem to symbolise that they have obtained/been granted/appropriated - grown - a voice of their own (Hobbs 2020).

Over the past few years, such angelic winged women - whether classified as angels or not featured in several works of African fiction - a term used here in the most encompassing way possible. These books were available in South African bookstores while, in the background, global campaigns like \#HeforShe and \#MeToo were coinciding with, and sometimes crosspollinating, an African-intellectual quest to decolonise, to bore through colonial crusts, into

\footnotetext{
${ }^{1}$ The financial support of the South African National Institute for the Humanities and the Social Sciences (NIHSS) is gratefully acknowledged. (Project CRP20-1032: African oral art in image-text objects: Cultural translations of precolonial memories and remains).
} 
forgotten heritage, for a vision towards the future. Spiritual journeys and encounters with the supernatural are a recurrent theme in these stories, set in commercialised, consumerist, (post) industrial "visual landscapes" (Houze 2016) of the twenty-first century (and beyond).

\section{Research questions}

How does one visually represent this yearning for a 'future of the past' amidst such cultural hybridity? What can we learn from the way book designers attempt to capture, foreground, and highlight stories of winged women on the covers of such works of fiction? And what does it mean if the best possible signifier to entice readers into visualising women's empowerment, escape, healing, transcendence, and voice, turns out to be a pair of feathery limbs? ${ }^{2}$

In the contemporary African fiction selected for this study, past signifiers of spirituality are frequently invoked from murky memory, and yet the visual representations in the cover art seem rather to draw on readily-available and easily-recognisable, globalised popular angel culture. Do book cover designers shy away from the labour of rigorous investigation into histories of African spirituality as inspiration? Ethnographic recordings of oral art which had still been performed by southern African communities while on the cusp of exposure to, and appropriation of, Christianity and European modernity, do exist. ${ }^{3}$ These could offer rich material for kindling visualisations of African spirituality. But the colonial formaldehyde in which the gaze and the grammar of such ethnographic recordings are often preserved, seems to be distancing and off-putting. And yet, the effort of airing, drying, and then peeling back the layers of such mediated memory harvested by interlocutors in colonial times, might still yield discoveries that could astonish the imagination. ${ }^{4}$

But is that always what readers want? Is that what book buyers, especially of fiction, expect to see? The picture on the cover must 'want' (in WJT Mitchell's terms) to translate the experience of seeing-by-looking into the semiotics of seeing-while-reading once the reader turns the cover. While the writer has the ability through text to create leaps and links between complex and multiple settings ranging from, say, quite specific aspects of African indigenous spirituality to churchy Christian backdrops, the signification on the cover of the book cannot be 'either/or'. The book cover must be provocative, inviting, and nebulous all at the same time: suggestive as well as elusive.

\section{Methodology}

The focus of this essay is not so much on the literary merit of the selected fiction, but on the book cover art, and the work it does to create a portal for potential readers into the book. I rely on information from the author and the illustrator themselves, some iconographic and semiotic interpretation of the 'messages' on the cover and in the text, and occasionally, where available, I also draw on affirmation from reviews by actual readers. Admittedly, within the confines of a single article, my treatment of each of these aspects in the production and consumption circuit is glaringly uneven. However, maintaining an ever-so-slight awareness of the full process is probably less skewing than highlighting only one or two aspects of this dynamic, interconnective, and highly contextual field of knowledge exchange. My major focus is on

\footnotetext{
2 Just as I was completing this essay, the 2021 call for submissions for the Sasol New Signatures Art Competition came out; the angelic female models on the advertising material are 'augmented' with wings drawn in behind their ears as if to suggest their creative spirits taking flight.

See https://www.sasolsignatures.co.za/

${ }^{3}$ See, for example, the Hoffmann Collection of Cultural Knowledge

https://rs.cms.hu-berlin.de/hoffmanncollection/pages/home.php

The northern Sotho folktales and folklore included in this collection feature numerous superhuman winged beings. Artist Tom Muff-Ford gave vivid visual expression to some of these in an Afrikaans translation of a selection of folktales published in 1940.

${ }^{4}$ For an example of such a venture, see Julia Wells (2012), The Return of Makhanda: Exploring the Legend, Pietermaritzburg: UKZN Press.
} 
Mohale Mashigo's collection of short stories Intruders, published by Picador in 2018, with an image for the cover (Figure 1) ${ }^{5}$ created by Shubnum Khan, an established writer herself. I contextualise Mashigo's book cover with reference to further examples of book covers featuring women with wings from commercial publishing houses representing local and diasporic African writers.

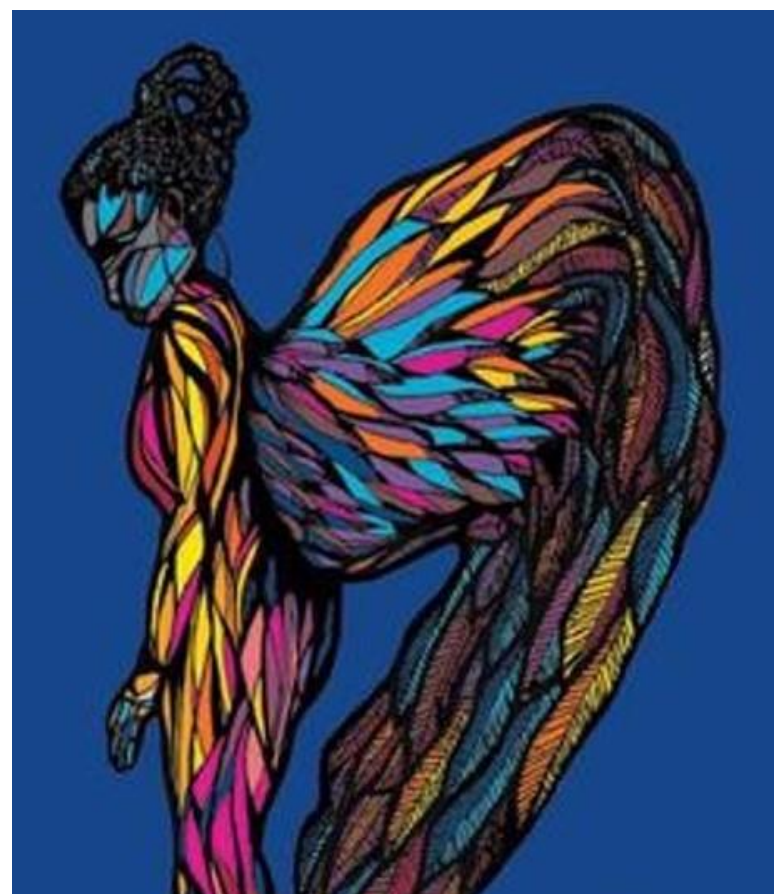

Figure 1: The cover art for Mohale Mashigo's book Intruders, created by Shubnum Khan and reproduced here with the kind permission of the artist.

\section{Book covers as a field of study}

With reference to what Mitchell (1980: 1) called the "interdisciplinary no man's land between the realms of word and visual image", Olivia Loots (2018: 1) explains that the study of book covers takes place on an "intermedial threshold". Book covers are one example of the "composite pictorial verbal forms" for which Mitchell had coined the concept imagetext and designed "picture theory", as explicated in his eponymous book. The work of Marco Sonzogni (2011: 15) focuses on book covers specifically, as they have evolved from 'dust jackets' over the past century. His research is grounded in Charles Rosner's mid-twentieth-century work on book cover design as "intersemiotic translation". Sonzogni's creation of a grid with criteria to determine the 'success' of a book cover, and his explanation of the function of the contemporary book cover as an "advertisement that uses primarily visual means to attract attention to the text", resonates with the reasoning within the book trade. The cover helps a great deal to sell the book (Le Roux \& Buitendach 2014: 24). Internationally renowned book cover designer, Peter Mendelsund, echoes the trade's needs and Sonzogni's estimation of what a successful cover should be, when he explains the designer's task as "setting the bar at 'make something as cool as possible that is as eye catching as possible that will hit all the proper notes and get this book into as many hands as possible'" (interview with Petit 2015: 42). What is remarkable of Mendelsund and his fellow book cover designers, however, is that they render this service to the book trade while also revelling in their own pleasure of reading.

\footnotetext{
${ }^{5}$ To view the complete cover, along with the publisher's synopsis of the book, visit the Pan MacMillan South Africa website: https://www.panmacmillan.co.za/books/intruders/9781770106338
} 
The seductive pleasure of reading, the enchantment and exhilaration of the experience - and our simultaneous association with reading culture as uplifting and ennobling (Jack, 2012; Bollmann, 2013), tend to mask the book cover's primary function as a foremost marketing tool in the publishing industry, which is as profit-driven as most others (Hagner, 2015). And yet readers quite readily tend to forgive a book with an enticing cover for being a commodity. Oddly enough, neuroscientific discoveries about the remarkable ways in which the brain operates while reading (Dehaene, 2009), seem to affirm this sense of the enchanting wholesomeness of reading.

Because the books (with their covers) chosen for this exploration focus strongly on spirituality and visual expressions of the unseen, the following musings of Mendelsund (2014) from his chapter "Memory and fantasy" in his book What we See when we Read, are worthy of an extensive quote:

Much of our reading imagination comprises visual free association. Much of our reading imagination is untethered from the author's text.

(We daydream while reading).

A novel invites our interpretive skills, but it also invites our minds to wander.

The reading imagination is loosely associative - but it is not random.

(Our reading imaginations may not be overtly coherent, but they are still meaningful.)

So, it occurs to me that perhaps memory - being the fodder of the imagination, and being intermingled with imagination - feels like imagination; and imagination feels like memory, being constructed of it as well.

Memory is made of the imaginary; the imaginary is made of memory.

With these remarks in mind, let us venture into Mashigo's imaginary world. She urges her readers to be fantastical "right now and in the future", providing the following explanation of fantastical: "conceived or appearing as if conceived by an unrestrained imagination; odd and remarkable; bizarre; grotesque" (Mashigo 2018: xv). As a writer of fiction, thus, she has no obligation to adhere to, represent, or respect the doctrine of any church or society or specific faith community, or to reflect their traditions correctly or accurately. Her fiction may bear witness to, and co-create with her book designer and her readers, something fantastical. However, the imagination might not be as unrestrained as the fantastical promises. As Mendelsund suggests, memory (that South African familiarity which Mashigo herself presents as the uniqueness to her stories), serves as "the fodder of imagination" and "intermingles" with the imagination. Mashigo appeals to contemporary South African readers' imaginings of the unseen with characters that are at home in the contemporary world of global multimedial entertainment, but who also carry memories of their elders' spirituality.

\section{Spirituality}

Before moving on to trace the book designers' task of distilling these processes of remembering and imagining in the book into a single cover image, let us for a moment consider the 'rational' human being's relationship with the unseen. Jaco Beyers (2021) proposes that Canadian philosopher Charles Taylor's concepts of the porous and the buffered self may be helpful in contexts (such as Mashigo's fiction) where the 'reality' of 'spirituality' plays itself out. Beyers (2021) explains that Taylor (2007: 34) does not ascribe the human perception of a spiritual realm to a particular worldview, but rather to an understanding of how the mind functions. For Taylor, if meaning is to be located within the human mind alone, then the self is buffered against spirits, demons, and powers, benevolent or malicious. When meaning is located exogenously, however, then meaning also resides in spiritual beings and objects 
carrying spiritual power. Thus, the boundaries between the seen world that humans reside in, and the unseen beings and powers, become porous, and the 'self' inhabits an enchanted world. The African fiction under review in this essay attunes readers to an enchanted world connecting the fate of human beings with magical forces. Rather than offering readers who would 'normally' think of themselves as buffered against the enchanted an imaginary world into which to escape, Mashigo's fiction appeals to readers' porous selves and greets them with a recognisable spirituality.

Ben Okri (2014: 26-27) explains it more poetically through the voice of his character Lao in his novel In Arcadia:

\begin{abstract}
... there is a mysterious veil that separates the living from the others. And this veil is made of perception. And don't ask me who the others are. They may be the dead. Except that the dead are not dead. They are just not alive in bodies. They may be angels, guardian angels, sinners and cynics that we are. They may be one's potent and powerful ancestors, shaking their heads in sadness at the enormous blunders that we are making in our lives. They may be illuminated beings. Who can say yeah or nay? They may sometimes even be demons, messengers of the devil, who use as many tricks to get to us as there are devices to save us. All I know is that there is a veil, and messages are projected through this veil
\end{abstract}

\title{
Meet the Intruders
}

Mohale Mashigo's Intruders is a collection of twelve short stories. Although one literary critic described several of these stories as beginnings of novels rather than short stories per se (Mashishi 2018), the overall reception was warm, especially in the press and on online platforms such as Goodreads, where it had 29 reviews by May 2021.

Mashigo herself wanted the book to be "about nobodies who discover that they matter" (Tsotetsi 2019). In the introduction to the book, she resisted the label Afrofuturism as "an escape for those who find themselves in the minority and divorced or violently removed from their African roots" and added: "It would be disingenuous of me to take Afrofuturism wholesale and pretend that it is 'my size'" (Mashigo 2018: xii, xv). In a response to interviewer Tsotetsi's remark that "some of the stories are inspired by or make reference to tales that many of us grew up on", the author replied: "[s]ome of our stories are so magical, scary and downright beautiful. I wanted to show people that there is value in what we have ... Our things are nice too!"

But then Mashigo is not a purist at all when it comes to "our things". In a conversation published in the Johannesburg Review of Books, she refers to her love of "comics and scary movies" (The Reading List 2018) and her insistence that they can also be set in Soweto and Mitchell's Plain, taking place within the familiarity of urban South Africa. Her memories from American popular culture - "Will Smith sav[ing] the world" (The Reading List 2018) - are but only thinly veiled in the imaginary world she creates in her short stories; she renders the familiar South African streets of Bloemfontein and the beaches of KwaZulu-Natal for readers who are, like herself, infused with an eclectic assembly of images considered local as well as imported. As the interviewer stated: "Quaggas, the Gruffalo, mermaids, werewolves, trainsurfing, Debora Patta, your references are diverse: global but also wonderfully local” (The Reading List 2018).

In the Goodreads reviews, readers mention how they recognised some references to folklore and urban legends they grew up with. Responding to the question of an interviewer about South African folklore as inspiration for "a lot of the book", Mashigo admitted that she only "did some research for the last story because I couldn't quite remember how the story of Tselane ${ }^{6}$

\footnotetext{
${ }^{6}$ The folk story of Tselane le dimo (Tselane and the giant) has been reproduced and analysed in various media, including children's readers and scholarly articles. See, for example, Nhlanhla Maake's (2017:
} 
ends. Seems there are many versions of that story. Other than that I just used what I grew up hearing (urban legends like Vera the ghost ${ }^{7}$ and others)" (The Reading List 2018).

With this, Mashigo's writer's imagination links up with how Mendelsund has described the reading imagination: "fed" on memory, it is "loosely associative". The reader-reviewers, having grown up in the same era and in similar visual landscapes as Mashigo, share the same nebulous field of associative imagery - and it is the task of the book cover designer to distil from this a single two-dimensional surface of image and text.

Looking too deeply into the authors' references - over-researching them, over- historicising them, might render the distillation unrecognisable to potential readers. The successful cover should elicit the familiar from the potential reader's horizon of expectation, and present it as if it is new, but in a welcoming way. The book cover does not want to serve as an 'educational moment' for readers, a demonstration of what a folktale-inspired enchanted being should look like, or most likely may once have looked like based on the oldest recordings of oral tradition. Rather, it is a mirror of contemporary popular culture: it should reflect to potential book buyers what they would find enchanting in the moment of this book's publication. Conveniently, as Gilhus (2019: 14) has found, angels "travel light". Accordingly, the cover image of Intruders had to be a radiant being with angelic wings, signified as an African woman, against a city skyline!

Several reviewers on Goodreads made complimentary references to this cover:

Muuka: Can I just start by saying that the cover of this book is beautiful.

They say don't judge a book by its cover but any reader will tell you that's absolute rubbish. We first investigate new writers and new books by their covers, read the blurb at the back, then decide whether it is worth reading. This book picked [sic] all the boxes. The cover art is as intriguing as the stories within.

Mack: Please don't think of me as a shallow reader when I say that I was sold on this short story collection because of its cover. This is a case where you can tell a book by its cover.

Priya Harry: I read about this book, saw the cover (yes, that's right, I judged a book by its cover) and knew I had to read it. It did not disappoint.

Deborah: l'll admit that the cover also very much caught my eyes!

What are the striking constitutive elements of the cover, recognisable to book-buying South Africans from their "cultural backpacks?" (Schama 1995: 7). Curiously, the actual readers who expressed their affinity for the cover, did not go into much description or verbal imaging thereof. At most they mentioned, like the artist herself, that the cover image relates specifically to the story of the high-heel killer, in which redemption comes for a woman who has killed a man in a rage of frustration. Wings start growing on her back, and they enable her to escape worldly justice and soar into the night sky above the city.

The genius of the cover design is that, when picking it up for the first time, potential book buyers do not yet necessarily have any of this information, and they cannot 'see' anything on the cover to prepare them for this unlikely, surprising, even improbable, plot of the story featured by the image. Therefore, the cover's initial appeal, prior to the reader having encountered any of the stories, does not hinge on any knowledge of the content of the book.

1-9) argument that the "higher level of discourse in folk narratives" should not be underestimated. Maake makes use of the version recorded by Eduard Jacottet, first published in 1909 by the Morija Sesuto Book Depot.

7 The "spirit of sinfully beautiful Vera, who is claimed to have haunted Vincent Road and Odendaal Street in Meadowlands, Soweto, in the 1950s and 60s", is now also the topic of a South African horror film, Vera the Ghost, written and directed by Martin Koboekae (Bambalele 2020). 
The connotations evoked by the cover image together with the title of the book must resonate unambiguously enough with the tastes of a community of readers significant in size to ensure sales of the book. The signifiers selected by the artist/designer must be recognisable to potential readers from their familiar visual landscapes to raise appropriate expectations about what is to be found in the book, while still promising the readers to be nourished, if not amazed. Much as I tried to reduce my own description of the cover to the naming of objects and colours, some commonly recognisable visual categories were hard to "bracket off" (Jordanova 2012: 24).

What follows here is an attempt at, firstly, listing what I can "see" when looking at the cover of the book in my hand (or at an image thereof on the publisher's website at https://www.panmacmillan.co.za/books/intruders/9781770106338).

Then, getting on with the work of observation and description, I add to the list those meanings that I can ascribe based on what I (and I believe I speak as an average South African bookbuyer) "know":

- Woman with wings.

- African woman with feathery wings fragmented into colourful segments: bright yellow, orange, blue, purple, pink, and grey.

- African woman with wings, looking as if they are made of stained glass, but with a grey city skyline and a dark blue night sky in the background.

- The author's name in the same grey as the city skyline printed in sans serif capital letters above the image of the woman.

- The word Intruders, printed in (friendly, not intrusive) decorative black letters underneath the woman's feet - the biggest letters on the cover, indicating the name of the book, with "short stories" printed underneath in smaller, white, sans serif capital letters.

- A recommendation to read the book by literary critic Lauren Beukes above the author's name.

- The logo of the publisher in the bottom right-hand corner.

- Where the angel [by now my cultural hardwiring has broken out of the brackets] is printed, the paper is embossed and feels smooth, while the matt finish of the blue night sky makes it feel deeper and darker.

Can I be sure of my association of the cover image with an angel and a church window? Mashigo herself uses the word angelic only once in her book, and then to describe the voice of the male protagonist in the first short story she introduces her readers to this character in a Christian church.

Church windows are the one place in the South African visual landscape where one can be sure to find radiant images of angelic, winged creatures built up from sections of colourful glass.

See the example of a stained-glass church window in Christ the King Catholic Church in Pretoria, with the Christ figure in the centre and two angels in the top right-hand corner (Figure 2). 


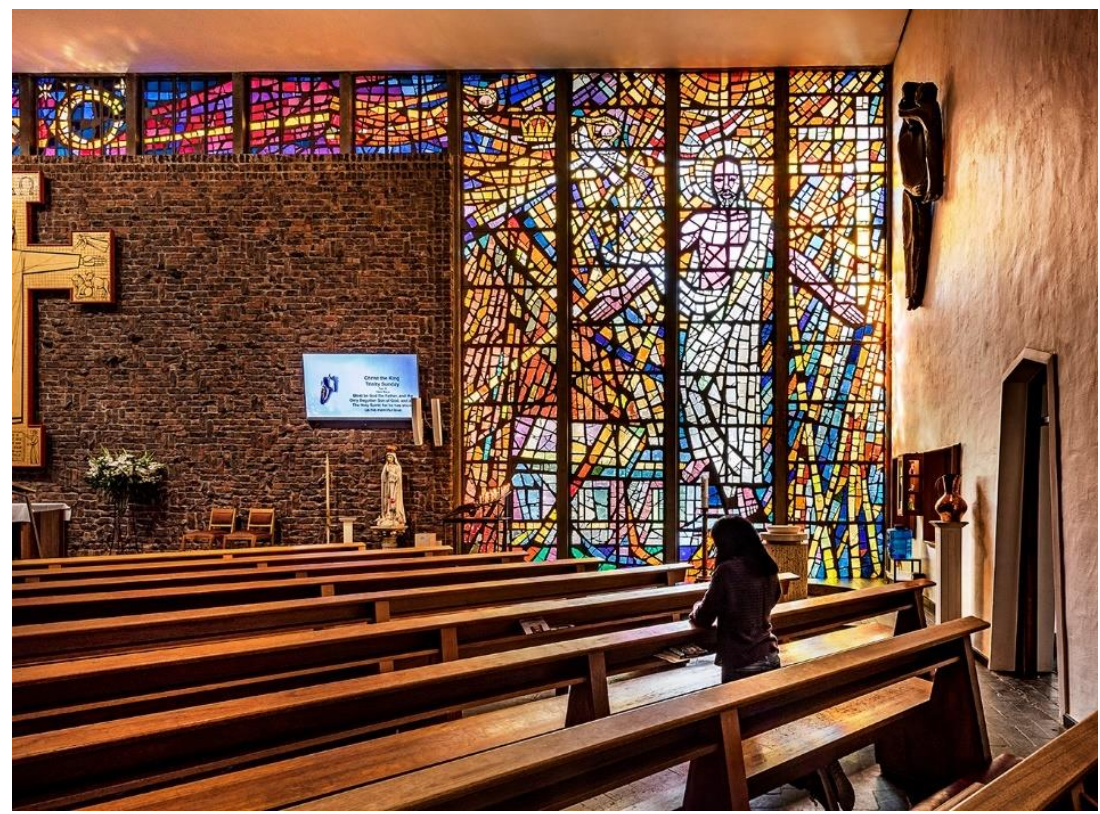

Figure 2: Leo Theron's cut glass and concrete work The Resurrection in Christ the King Catholic Church in Pretoria. Reproduced with kind permission of Alain Proust and Johan Swart, Hidden Pretoria (2019: 189).

The translucent radiance of stained-glass (church windows), speaks not only to the story of the high-heel killer in which the protagonist is transformed into a winged figure of power, but also relates to the theme of spirituality that runs throughout Mashigo's book. Besides the cover image, two more of artist Shubnum Khan's enchanting illustrations were included inside the book (see Figure 3).

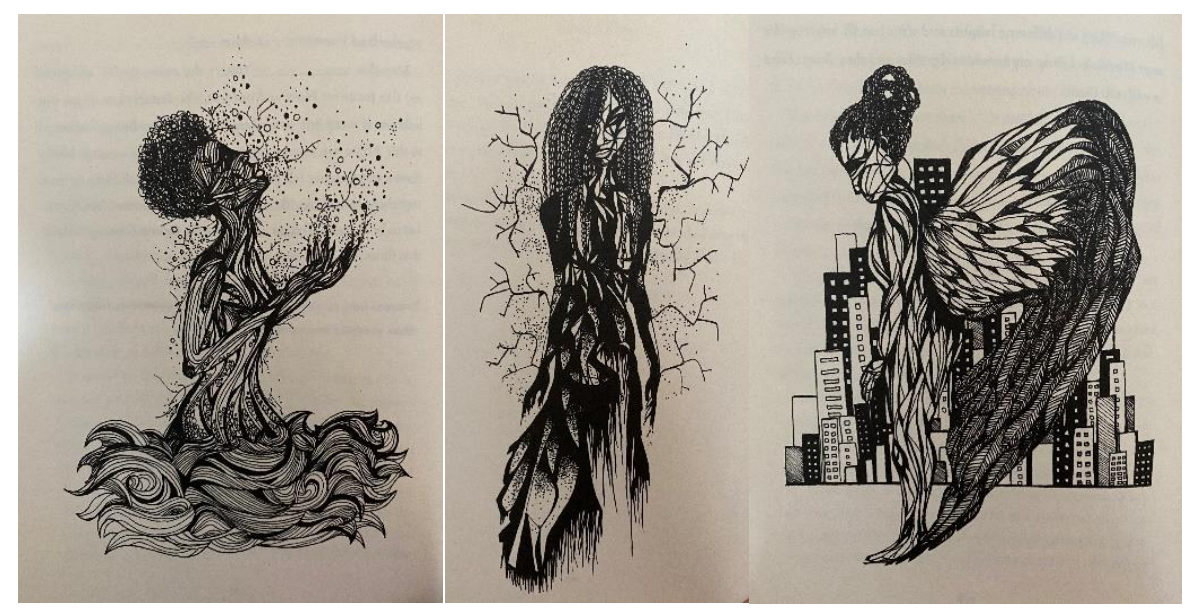

Figure 3: Shubnum Khan's art works as reproduced inside Mashigo's book to introduce each of the three sections into which the short stories are divided: "The Good", "The Bad", and "The Colourful".

The first is of an African woman immersing herself and becoming a creature of the sea, (an inversion of the Venus Rising from the Sea of canonical Western art iconography?). This image introduces the first section of stories about "The Good'. The second is a scary image of the seductive ghost for the part titled "The Bad." The third is the cover image of the woman with the angelic wings, accompanying the final section entitled "The Colourful". Although not illuminated in colour inside the book, Khan's images are built up in small angular sections that invite a multi-perspectival approach to something different from the ordinary, seen world; a 
glimpse into the unseen, the imaginary, the fantastical. Such are the "intruders" as announced in the title of the collection and in the cover art: part superhuman, part spirit, part ancestral, good, bad, colourful, and beautiful. They seem capable of transcending the reach of ordinary humans in space and over time. ${ }^{8}$

In an investigation into the symbolic meaning of nineteenth-century stained-glass art in Europe and the Americas, Cheney (2016: 1) and her fellow researchers found that "the narrative for the figurative design drew from the Bible, mythology, history, literature, and the symbolism of the time, including themes on popular culture such as ecology and materiality".

Mashigo has drawn from a similarly broad range of categories in the construction of her book's settings and characters, and Khan's illustrations, like windows, give visual expression to these memory-fantasy associations in ways that have resonated with at least a couple of actual readers who posted reviews online.

Cheney (2016: 1) further explains that the aim with the nineteenth-century revival of the medieval and renaissance art form of stained-glass imaging was "to reveal metaphorically spiritual blessings through the heavenly light." She also refers to the "mystical powers", "beauty" and "spiritual delight" associated with stained-glass windows. These associations also resonate with Mashigo's aims with her stories. Stained-glass art is not alien to African visual landscapes. South Africans live with stained glass both as remnants of nineteenth- and early twentieth-century colonial architecture, as well as the modern twentieth-century city churches that taxis like the one used by the urban characters in Mashigo's stories pass by every day. ${ }^{9}$

\section{Feathery context}

It would be speculative to argue whether either Mashigo or Khan had looked at existing African fiction featuring wings on book covers, but even a quick online search into African writers (continental and diasporic) confirms that the context exists. In 2000, Keenan Pendergrass' book of inspirational poetry in African American church tradition, featured an angelic woman with outspread wings in green and gold on the cover. For its 2014-editions of Ben Okri's novels Astonishing the Gods (1995), Dangerous Love (1996), In Arcadia (2002), The Age of Magic (2014), and essays in A Way of being Free (1997), designer Leo Nickolls at HeadofZeus publishers sustained the theme of wings - butterfly's, bird's, and angel's - throughout all five designs.

\footnotetext{
${ }^{8}$ Understandably, the artist did not elaborate extensively on her work in email correspondence with me, rather leaving the interpretation open for readers to fill in - 'daydream' as they please, according to Mendelsund. Khan did explain that she had worked with the author to create the image. On the topic of wings also featuring in some of her other artworks available online, she explained that wings "represent a freedom of sorts, or an escape" to her (Khan, 13 October 2020).

9 Throughout the 1990s and well into the 2000s, Kevin Shillington's widely-used textbook History of Africa featured a stained glass window depicting a black African Saint George slaying the Dragon.
} 

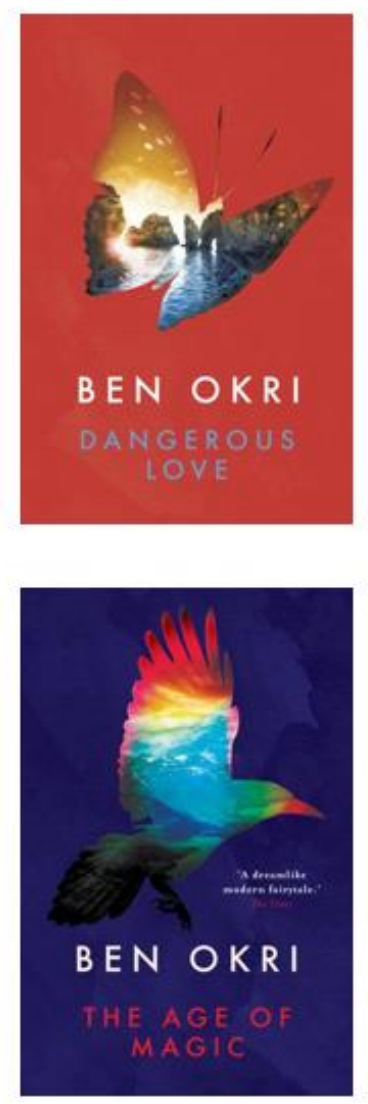
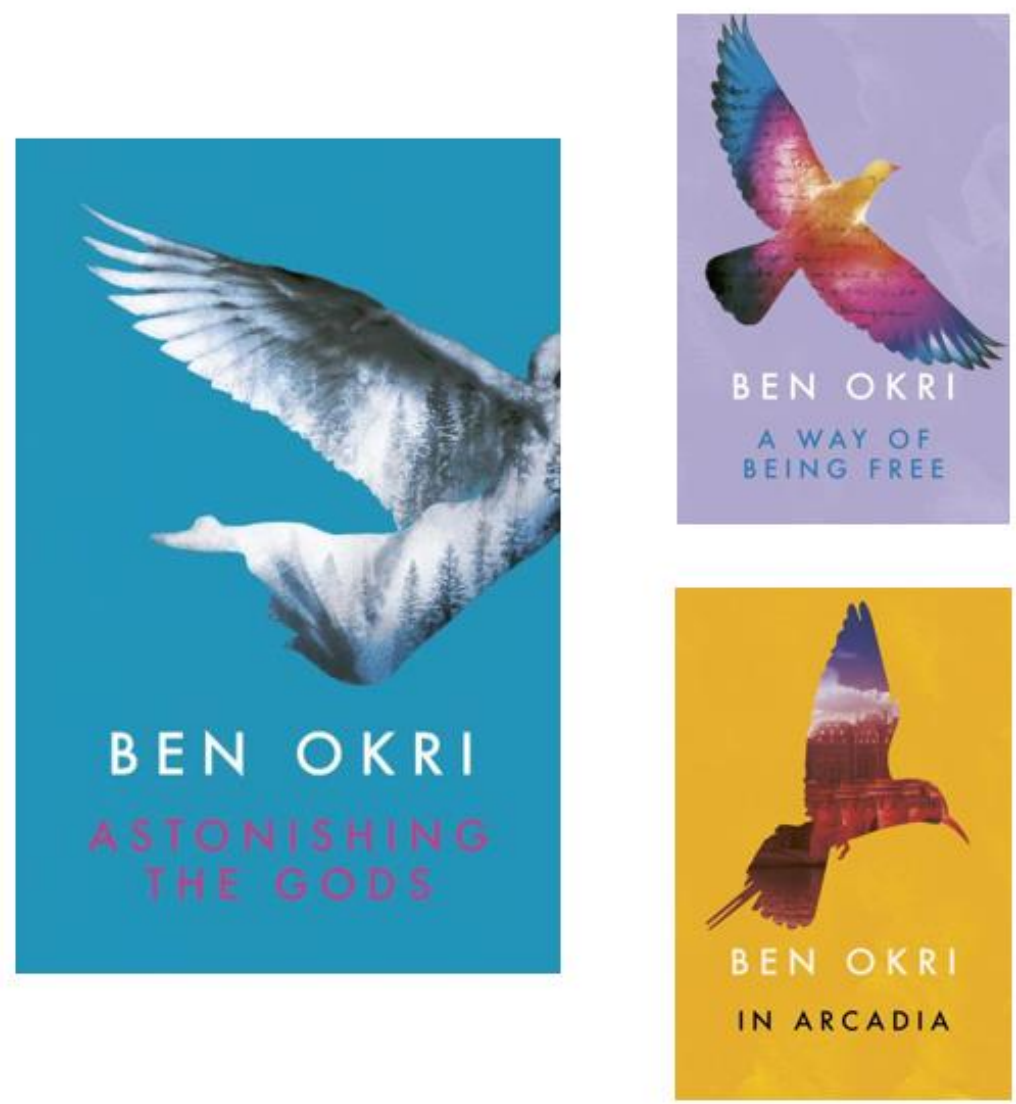

Figure 4: The cover images designed by Leo Nickolls for the 2014 editions of five of Ben Okri's books. Reproduced with the permission of HeadofZeus publishers.

In all these Okri publications (see Figure 4), the association of wings with giving flight and the connotation of wings with spiritual journeys and angelic power, are prevalent. According to Okri scholar Rosemary Gray (2021: xi), the author's oeuvre invokes "resonances of the resilient cultural, existential and spiritual identity." Gray continues: "Okri transmogrifies the ingenuity, artistry and imaginative force of our society through narrative allegory and personal revelation, transmuting the anxieties of politico-historical conditions into a unique alchemy of symbolist imagery to penetrate behind reality in search of an ideal world." Nickolls filled the outlines of the winged creatures in all five covers with such symbolic Okri imagery: silent, snowy forests within the angel; tranquil waters with the dawn of a new world behind the rocks in the butterfly; palatial majesty within the sunbird; radiant colours breaking out above the mountains within another. On the cover of $A$ Way of being Free, the bird's body and wings are covered in handwriting including words like you, silence, time, songs, kingdom, and tortoise, set against a background of magical blue and purple. Rather literally, this application of script on image provides a visual portal for the readers to adjust their mode of seeing from looking to reading - as if wings can carry us from the material into the spiritual realm. The way the angel is positioned on the cover of Astonishing the Gods (flying 'over' the edge), also urges the person holding the book to open it, to follow her inside, into the enchanted dimension.

A winged woman also appears on the cover of Marelize Hobbs's Afrikaans novella Voëlvrou (Bird woman) (Protea, 2020) advertised at https://proteabooks.com/index.php/voelvrou.html. The cover art by Suzanne du Toit features a naked woman. Crouching, with her arms wrapped around her knees; cupped into her own white wings acting like enormous protective hands, she gives the viewer a penetrating look. The red background shining through behind her wings, makes a halo-of-sorts above her head. In the story, Hobbs's winged character feeds 
on magical water, and its rejuvenating energy transforms her from a white girl into a black woman. The Tswana people who have found her, call her lenyoloi - angel (Hobbs 2020: 23). The novella is set at the time of Easter and besides some invocations of African spirituality, the bird woman also becomes a sacrificial lamb-like Christ. There are also some connotations with the Phoenix myth of rebirth.

This myth is foregrounded with the title and the cover art of The Book of Phoenix (London: Hodder \& Stoughton, 2016), a fantasy novel by Nigerian-American author Nnedi Okorafor with illustrations by Eric J. Battle (See bookmall.co.za for the cover of the book I purchased in South Africa and https://nnedi.com/books/book_of_phoenix.html for an even more angelic image on a 2017 edition published by Daw Books). Okorafor is perhaps best known as the creator of the Black Panther Marvel Comic-turned blockbuster movie. In a number of respects, Okorafor is comparable with Mashigo, who is the writer of the South African comic series Kwezi. But while Mashigo has already distanced herself from Afrofuturism in the introduction to Intruders in 2018, Okorafor had initially identified with the genre. In a defining statement in a 2020 publication, she rather opted for 'Africanfuturism and Africanjujuism' (Gasser 2021). And yet by stating that "Africanfuturism is specifically and more directly rooted in African culture, history, mythology and point-of-view" (Okorafor 2020: ix), she does not position herself on the same page as Mashigo. Okorafor's characters fly over New York and wield power from Wakanda, while Mashigo's travel in taxis in downtown Jozi and make love on Durban beach sand. And yet, much as the details are filled in differently according to local sights and sounds, the visions invoked by the authors, and translated into graphics on the covers of their books, can be reduced to strikingly similar signifiers: The Hodder \& Stoughton cover of Okorafor's Book of Phoenix features exactly the same elements as Mashigo's Intruders: Skyscrapers and a winged African woman rising above them.

\section{Old wives' tales alive in the city}

The message from these covers seems clear: African women are asserting themselves in (post)modern urban spaces, and they keep just enough of what the past has to offer them as is necessary to navigate their presence in their present moment, as they determine their new futures. These winged women have come a long way when one thinks of Drum magazine's editor Antony Sampson's (1956: 20) often quoted recollection of what 'the black man' in the South African city 'wanted' in the 1950s:

Tribal music! Tribal history! Chiefs! We don't care about chiefs! Give us jazz and film stars, man! We want Duke Ellington, Satchmo, and hot dames! Yes, brother, anything American. You can cut out this junk about kraals and folk-tales and Basutos in blankets—forget it! You're just trying to keep us backward, that's what! Tell us what's happening right here, man, on the Reef!

Looking back more than half-a-century later, the folktales still linger ... and the 'hot dames'? No. The women are stretching their wings and speaking for themselves, saying what they want. Against the fainting beats of Drum's mid-century male-dominated African modernity, one hears Mashigo's (2018: xv) alternative agenda (pun intended) for the new millennium: "Let us use our folktales as need be - use them to imagine us being fantastical in this Africa we occupy right now."

In this light, the cover's striking appeal makes even more sense. Think "loosely associative", but "not random" and perhaps not "overtly coherent", but "meaningful" à la Mendelsund - and ... That a struggling woman who had just killed a taxi-driver with her high-heel shoe will rise above the city like a phoenix in the radiant colours of a church window, is then probably exactly what over half a century of black women's assertion of their right to the South African city had to accumulate to in visual memory. Gwen Ansell's (2016) observation with reference to the characters in Okorafor's Book of Phoenix, that "regular readers of fantasy know exactly what's coming when characters develop itchy growths around their shoulder blades" is perhaps 
equally applicable to Mashigo's high-heel killer. But the cover image for Mashigo's collection of short stories also speaks to more than just the particulars of that one story. Taking a cue from Mendelsund again: "Much of our reading imagination comprises visual free association. Much of our reading imagination is untethered from the author's text." The angelic winged woman on the cover is capable of standing for - no, hovering over, the full syncretic range of spirituality woven into the stories.

In several stories in Intruders the characters refer to an older generation - mothers or grandmothers - having grown up in Christian contexts. The setting of 'Manoka', the first story, is a church trip, and Manoka's boyfriend is the "lead tenor of the choir with an angelic voice" (2018: 4). In "Untitled i" Bonolo throws "a Sesotho Bible that had belonged to their mother's aunt" (2018: 61) into her sister's suitcase as one of the possessions to accompany her into outer space when escaping earth's destruction. It is also in this story that the author uses "God/the ancestors" to refer the spiritual powers that measure out life's conditions to 'the people'. This catch-all phrase encompasses familiar forms of South African syncretism, including those worshipping the Christian God, those revering their ancestors, as well as those who do both, either simultaneously or as appropriate per occasion. "God/the ancestors" conjoins precolonial memories of pre-Christian spirituality and colonial experiences of Christian schooling. It also marks the convergence of oral performance with reading-writing into an irrevocably-intermedial transfer and translation of knowledge post-colonially.

The medium thus becoming the message (as McLuhan (1964) had proclaimed), culminates in the final story, 'Nthatisi', where the knowledge of folklore, prophesies and folk stories have, as with Christian practices, not thoroughly percolated down to the younger generation represented by the protagonist. But from the droplets of memory that trickle through, the fantastical can be conjured. The character in the story has to learn from a letter left by her mother that they are ancestors of the Tselane in the folktale who had to hide from a humaneating villain - and that the red cloak she knows from Red Riding Hood fame is real - and can make her invisible. There is also a secret book in Sesotho which will provide answers to all her questions, compensating for what her mother had failed to teach her. The letter, the cloak, the book - each is an object carrying spiritual power, with the meaning residing in the object (as Beyers had explained with reference to Taylor), regardless of the protagonists' worldview.

Why is it not surprising that such an associative mix between oral tradition (folklore, prophecies wrapped in folktales) and letters and books would resonate with Mashigo's (implicit and actual) readers? The print culture of southern Africa's Bantu languages had historical beginnings in Christian missionary presses and missionary schools. And folktales were one dimension of oral culture that not only persevered on their own account, but were also reproduced - albeit often Bowdlerised - for African children in school textbooks in their indigenous languages, and for children of European descent in translated versions. These circulated in South Africa alongside Biblical stories, secular fiction and educational material in the European-Christian tradition throughout the twentieth century. The Goodreads online commentary of Mashigo's story bears testimony to the lingering patina of the folktale, not just in the imagination of the author, but also in the consciousness of actual readers.

One reader, Sipho Lukhele, found the folktales "really familiar, but very much [...] reimagined" Like the author herself, another reader, Welhermina, confessed that she forgot "how the Tshelane le Modimo tshomo starts or ends", and that she "must find an actual adult to go over such things with". This notion of a community's perpetual sense of loss is of course not necessarily as apocalyptical as suggested in the fiction, but can also be explained, as had been done by Panofsky and more recently and more famously by Bourdieu, as habitus, a continual process of improvisation through intergenerational transfer (Burke 2004: 56-57). A spiritual herald might help to pass the culture on, spread the message, and interpret it. And there she is, on the book's cover, ready with her wings. 


\section{Conclusion}

Mashigo does not once use the word 'angel' in her book, but the cover image invokes enough of what, in the broadly shared universal popular reading culture of our time, alludes to the spiritual world. The translucent winged creature on the cover works as messenger between the seen and the unseen; by association, the cover image invites readers to succumb to their porous selves, to accept the messages from behind 'the veil' as Okri (2014: 26) refers to it. The winged African woman is a recognisable graphic image for readers who will also find Mashigo's verbal image-building in the text familiar. In Mendelsund's words, it sets the readers' interpretive skills at work, but also allows their minds to wander - or fly, like those angels we see in church windows.

In my research question I asked how a yearning for a 'future of the past' can be visually represented amidst cultural hybridity. In conclusion, it seems that there is only a hybrid way. In order to suggest something as irretrievable as the past, book cover designers have nothing else to draw on but symbols and signifiers that are familiar to themselves and their audience in their own time. Consequently, imaginary representations of the past inevitably mirror the visual landscapes of the moment in their very effort to escape them. Unsurprisingly, this is also the message Mashigo conveys in the introduction to Intruders. Her call for being "fantastical in this Africa we occupy right now" (2018: xv) goes out to, as she states in her author's note (and she counts herself among them): "lost souls with praying mothers" (2018: vii). Mothers pray for angels to guard their children. If in the twentieth century angels have tended to be imagined as female helpers of others, Mashigo's winged superhero women of the twenty-first century in Africa are imagined as adhering, at last, first and foremost (in Ibsen's nineteenth-century words), to the duties to themselves. ${ }^{10}$

\section{References}

Ansell, G. (2016). Nnedi Okorafor's novel 'The Book of Phoenix' is a fantasy rooted in African reality. Mail \& Guardian Friday, 9 August. https://mg.co.za/article/2016-08-09-00-nnediokorafors-novel-the-book-of-phoenix-is-a-fantasy-rooted-in-african-reality/ Accessed: 7 July 2021.

Bambalele, P. (2020). Legend of Vera the ghost inspires new SA horror film. Sowetan Live Entertainment, 22 May. https://www.sowetanlive.co.za/entertainment/2020-05-22-legend-ofvera-the-ghost-inspires-new-sa-horror-film/ Accessed: 25 April 2021.

Beyers, J. (2021). Appropriating spiritual help for traditional healing: why ancestors are needed. Pharos Journal of Theology 102, Special Edition 1.

Bollmann, S. (2013). Frauen und Bücher. Eine Leidenschaft mit Folgen, Munich: Deutsche Verlags-Anstalt.

Bourdieu, P. (1990). The Logic of Practice. Cambridge: Polity Press.

Burke, P. (2004). What is Cultural History? Cambridge: Polity Press.

DeHaene, S. (2009). Reading in the Brain, New York: Penguin.

Cheney, LdG. (2016). Radiance and Symbolism in Modern Stained Glass: European and American Innovations and Aesthetic Interrelations in Material Culture, Cambridge: Cambridge Scholars Publisher. ProQuest Ebook Central, http://ebookcentral.proquest.com/lib/pretoriaebooks/detail.action?docID=4535122 Created from pretoria-ebooks Retrieved 16 April 2021.

${ }^{10}$ Henrik Ibsen, A Doll's House (1879). 
Goodreads. (2021). Intruders: Short Stories by Mohale Mashigo. Available at: https://www.goodreads.com/book/show/42103684-intruders Accessed 2 May 2021.

Gasser, L. (2020). Afrofuturism and Africanfuturism. In A. von Rath \& L. Gasser (Eds.), Poco.lit Platform https://pocolit.com/en/2020/11/23/afrofuturism-and-africanfuturism/ Accessed 28 April 2021.

Gilhus, IS. (2019). On the category of angels. In IS. Gilhus, A. Tsakos \&MC. Wright (Eds). The Archangel Michael in Africa. History, Cult, and Persona, London: Bloomsbury. 11-21.

Gray, R. (2021). The Touch Alchemy of Ben Okri. The Writer as Conceptual Artist, London: Bloomsbury Academic.

Hagner, M. (2015). Zur Sache des Buches, Göttingen: Wallstein.

Hobbs, M. (2020). Voëlvrou, Pretoria: Protea.

Hobbs, M. (2020). Interview with the author by Analize Viljoen and Trisa Hugo, Boekemakranka, 8 October 2020. https://www.youtube.com/watch?v=_IOBEjABeU8

Hoffmann, C.A. (ed.) (1930). Bantoestories uit Transvaal. Translated from Sepedi by GH. Franz and with illustrations by JWD. Muff-Ford, Cape Town: Nasionale Pers.

Houze, R. (2016). New Mythologies in Design and Culture. Reading Signs and Symbols in the Visual Landscape. London: Bloomsbury.

Jack, B. (2012). The Woman Reader, New Haven: Yale University Press.

Jordanova, L. (2012). The Look of the Past. Visual and Material Evidence in Historical Practice, Cambridge: Cambridge University Press.

Joubert, A. (ed.) (2015). The Hoffmann Collection of Cultural Knowledge. Available at: https://rs.cms.hu-berlin.de/hoffmanncollection/pages/home.php Accessed 1 May 2021.

Khan, Shubnum. (2020). Email correspondence with author, 13 October.

Le Roux, E. \& Buitendach, S. (2014). The production and reception of Deon Meyer's works: an evaluation of the factors contributing to bestseller status. Scrutiny2 19 (1). 18-34.

Loots, O. (2018). Translating word to image. A comparative intermedial study of frame in the Snow's two covers. Honours research paper, University of Pretoria, Pretoria.

Maake, N. (2017). A strategic analysis of the folktale of Tselane le Modimo. Southern African Journal of Folklore Studies 27 (1). 1-9.

Mashigo, M. (2018). Intruders. Johannesburg: Picador Africa.

Mashishi, N. (2018). Review: Intruders by Mohale Mashigo. Wits Vuvuzela, October 2018. Available at: witsvuvuzela.com/2018/10/10/review-intruders-by-mohale-mashigo/ Accessed 10 October 2020.

McLuhan, M. (1964). Understanding Media. The Extensions of Man, New York: McGraw-Hill.

Mendelsund, P. (2014). What we See when we Read. A Phenomenology, New York: Vintage. Kindle version.

Mitchell, W.J.T. (1980). What is an image? New Literary History 15 (3). 503-537.

Mitchell, W.J.T. (1994). Picture Theory. Essays on Verbal and Visual Representation, Chicago: Chicago University Press.

Okorafor, N. (2016). The Book of Phoenix, London: Hodder \& Stoughton. 
Okorafor, N. (2020). Africanfuturism defined. In W. Talabi (Ed.), Africanfuturism. An Anthology. Brittlepaper, s.l. ix-xi.

Okri, B. (1996, new edition 2014). Dangerous Love, London: HeadofZeus.

Okri, B. (1998, new edition 2014). A Way of Being Free, London: HeadofZeus.

Okri, B. (2002, new edition 2014). In Arcadia, London: HeadofZeus.

Okri, B. (2005, new edition 2014). Astonishing the Gods, London: HeadofZeus.

Okri, B. (2014). The Age of Magic, London: HeadofZeus.

Petit, Z. (2015). The evolution of Peter Mendelsund. Print 29 (2). 40-43.

Pior, B. (2020). Email correspondence with author, 27 November.

Sampson, A. (1956). Drum. A Venture into the New Africa. London: Collins.

Schama, S. (1995). Landscape and Memory. New York: A. Knopf.

Sonzogni, M. (2011). Re-covered Rose: Case Study in Book Cover Design as Intersemiotic Translation, Philadelphia: John Benjamins.

Swart, J. \& Proust, A. (2019). Hidden Pretoria, Cape Town: Struik.

Taylor, C. (2007). A Secular Age, Cambridge, Massachusetts: The Belknap Press of Harvard University Press.

Tsotetsi, P.B. (2019). Mohale Mashigo discusses Intruders with .... Sunday Times, 10 January. Available at https://www.timeslive.co.za/sunday-times/books/news/2019-01-10mohale-mashigo-discusses-intruders-with-pearl-boshomane-tsotetsi/ Accessed 1 October 2020.

The Reading List (2018). 'Why can't a girl from Soweto become a mermaid?' Mohale Mashigo chats about her new Book, Intruders. The Johannesburg Review of Books, 5 December. Available at: https://johannesburgreviewofbooks.com/2018/12/05/sponsored-why-cant-a-girlfrom-soweto-become-a-mermaid-mohale-mashigo-chats-about-her-new-book-intruders/ Accessed 1 October 2020. 